\title{
SYNTHESIS, CHARACTERIZATION AND ANTIBACTERIAL ACTIVITIES OF NOVEL MIXED LIGANDS (AZO ANILS AND OXALATE ION) COPPER(II) COMPLEXES
}

\author{
Muhammad Ameen ${ }^{1 *}$, S.R. Gilani ${ }^{1}$, Amina Naseer ${ }^{1}$, Ishrat Shoukat ${ }^{1}$ and S.D. Ali ${ }^{2}$ \\ ${ }^{1}$ Department of Chemistry, University of Engineering and Technology, Lahore-54890, Pakistan \\ ${ }^{2}$ Nano Science and Catalysis Division, National Centre for Physics, Islamabad-45320, Pakistan
}

(Received October 20, 2014; revised September 7, 2015)

\begin{abstract}
Three azo anils ligands; 4-[(4-nitrophenyl)diazenyl]-2-[(phenylimino)met-hyl]phenol (L1), 2$\{[(2-$-methylphenyl)-imino]-methyl $\}-4-[(4-$ nitrophenyl)diazenyl]phenol (L2) and 2-[(naphthalen-1-ylimino)methyl]-4-[(4-nitrophenyl)diazenyl]-phenol (L3) were synthesized and characterized using elemental analysis, FT/IR spectroscopy, ${ }^{13} \mathrm{C}$ and ${ }^{1} \mathrm{H}$ NMR spectroscopy and UV-Vis spectroscopy. Similarly three mixed ligand complexes, $\{(\mathrm{L} 1) \mathrm{Cu}(\mathrm{II})(\mathrm{OX})\},\{(\mathrm{L} 2) \mathrm{Cu}(\mathrm{II})(\mathrm{OX})\}$ and $\{(\mathrm{L} 3) \mathrm{Cu}(\mathrm{II})(\mathrm{OX})\}$ constituting of azo anils and oxalate ion were also synthesized and characterized using elemental analysis, atomic absorption spectroscopy, FT/IR spectroscopy and UV-Vis spectroscopy and square planner geometry was suggested for $\mathrm{Cu}(\mathrm{II})$ complexes. Antibacterial activities of free ligands (azo anils and oxalate) and $\mathrm{Cu}(\mathrm{II})$ complexes were determined. Gram positive (Bacillus subtilis and Staphylococcus aureus) and Gram negative (Enterobacter aerogenes and Escherichia coli) bacteria were used for antibacterial study. The results have shown that $\mathrm{Cu}(\mathrm{II})$ complexes have privileged antibacterial activities compared to free ligands. The enhancement in antibacterial activities of transition metal complexes compared to corresponding free ligands may be attributed to structural symmetry of transition metal. The order of antibacterial activities of transition metal complexes, $\{(\mathrm{L} 1) \mathrm{Cu}(\mathrm{II})(\mathrm{OX})\}>$ $\{(\mathrm{L} 2) \mathrm{Cu}(\mathrm{II})(\mathrm{OX})\}>\{(\mathrm{L} 3) \mathrm{Cu}(\mathrm{II})(\mathrm{OX})\}$.
\end{abstract}

KEY WORDS: Azo anils, Oxalate ion, Mixed ligands $\mathrm{Cu}(\mathrm{II})$ complexes, Spectroscopic study, Antibacterial activities

\section{INTRODUCTION}

Schiff bases are gaining a centre of attention for biochemist due to their medicinal properties and are being used in medicinal products [1]. Schiff bases with azo group and their transition metal complexes have displayed antibacterial and antifungal activities [2]. The azomethine $(-\mathrm{C}=\mathrm{N}-)$ group in azo Schiff bases introduced an exposure to biochemical mechanism in biological system [3-4]. It has been described earlier that biochemically active compounds proved higher antibacterial activities when coordinated to central metal atom in compared to free ligand [5]. Biomedicinal characteristic of free azo Schiff base ligands upon coordination to central metal atom led the complexes for numerous biomedicinal functions such as therapeutically energetic analgesic properties [6], anti-inflammatory [7], antiviral [8] and antibacterial [9].

Here we are reporting antibacterial activities of three newly synthesized azo anils ligands and their three mixed ligands complexes with $\mathrm{Cu}(\mathrm{II})$ complexes using oxalate ion as second ligand. The azo anils ligands are: 4-[(4-nitrophenyl)diazenyl]-2-[(phenylimino)methyl]phenol

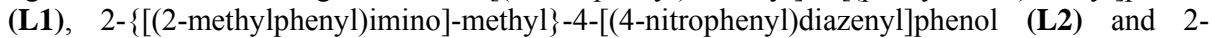
[(naphthalen-1-ylimino)methyl]-4-[(4-nitrophenyl)-diazenyl]-phenol (L3). The antibacterial activities of azo anils ligands were enhanced after coordination with $\mathrm{Cu}$ (II) ion. This is due square planner geometry of synthesized copper(II) complexes.

\footnotetext{
*Corresponding author. E-mail: ch.ameen86@gmail.com
} 


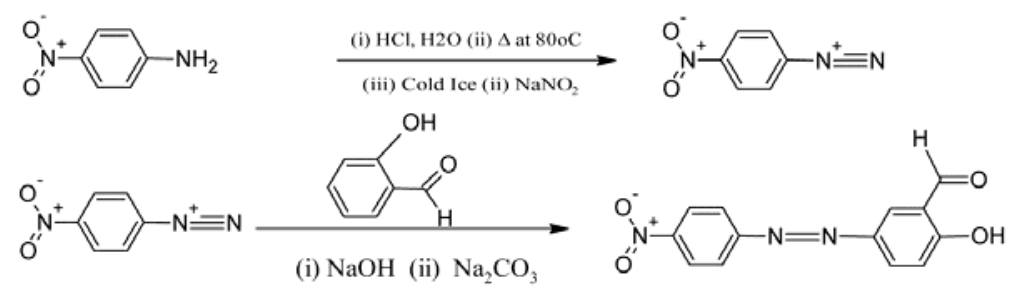<smiles>CC[13C](=O)c1ccc(N=Nc2ccc([N+](=O)[O-])cc2)cc1C=O</smiles>
Ethanol, Refluxed for $2-3 \mathrm{~h}$

(L1)<smiles>CC[14CH2]c1cccc(N)c1N</smiles><smiles>Cc1ccccc1/N=C/c1cc(N=Nc2ccc([N+](=O)[O-])cc2)ccc1O</smiles><smiles>O=Cc1cc(N=Nc2ccc([N+](=O)[O-])cc2)ccc1O</smiles><smiles>NC1C=CCc2ccccc21</smiles><smiles>O=[N+]([O-])c1ccc(N=Nc2ccc(O)c(C=Nc3cccc4ccccc34)c2)cc1</smiles>

(L3)

Scheme 1. Steps involved in the synthesis of azo anils ligands.

Table 1. Physical and analytical data of ligands and complexes.

\begin{tabular}{|c|c|c|c|c|c|c|}
\hline \multirow{2}{*}{ Compounds } & \multirow{2}{*}{ Color } & \multicolumn{4}{|c|}{ Elemental anal. calcd./found } & \\
\cline { 3 - 7 } & & $\mathrm{C}$ & $\mathrm{H}$ & $\mathrm{N}$ & $\mathrm{Cu}(\mathrm{II})$ & m.p. $\left({ }^{\circ} \mathrm{C}\right)$ \\
\hline L1: $\mathrm{C}_{19} \mathrm{H}_{14} \mathrm{~N}_{4} \mathrm{O}_{3} \cdot \mathrm{H}_{2} \mathrm{O}$ & Reddish brown & $62.63 / 62.60$ & $4.43 / 4.45$ & $15.38 / 15.45$ & - & $205-207$ \\
\hline L2: $\mathrm{C}_{20} \mathrm{H}_{16} \mathrm{~N}_{4} \mathrm{O}_{3} \cdot \mathrm{H}_{2} \mathrm{O}$ & Bright brown & $63.48 / 63.49$ & $4.79 / 4.79$ & $14.81 / 14.78$ & - & $240-245$ \\
\hline $\mathbf{L} 3: \mathrm{C}_{23} \mathrm{H}_{16} \mathrm{~N}_{4} \mathrm{O}_{3} \cdot \mathrm{H}_{2} \mathrm{O}$ & Yellow green & $66.66 / 66.65$ & $4.38 / 4.39$ & $13.52 / 13.52$ & - & $270-275$ \\
\hline$\left\{\left(\mathrm{L}_{1}\right) \mathrm{Cu}(\mathrm{II})(\mathrm{OX})\right\}$ & Brown & $50.76 / 50.74$ & $2.64 / 2.62$ & $11.28 / 11.30$ & $12.79 / 12.81$ & $>350$ \\
\hline$\left\{\left(\mathrm{L}_{2}\right) \mathrm{Cu}(\mathrm{II})(\mathrm{OX})\right\}$ & Yellow brown & $51.72 / 51.70$ & $2.96 / 2.93$ & $10.97 / 10.98$ & $12.44 / 12.46$ & $>350$ \\
\hline$\left\{\left(\mathrm{L}_{3}\right) \mathrm{Cu}(\mathrm{II})(\mathrm{OX})\right\}$ & Light brown & $54.90 / 54.93$ & $2.76 / 2.73$ & $10.24 / 10.23$ & $11.62 / 11.65$ & $>350$ \\
\hline
\end{tabular}

\section{Chemicals}

\section{EXPERIMENTAL}

Analytical grade chemicals; $\mathrm{CuCl}_{2} \cdot 2 \mathrm{H}_{2} \mathrm{O}$, DMSO, methanol and ethanol were purchased from Aldrich chemicals. The other chemicals such as aniline, methyl aniline, 1-naphthylamine and oxalic acid were purchased from BDH. All chemicals were used without any further purification, except vacuum dried over calcium chloride.

\section{Instrumentations}

$\mathrm{C} \mathrm{H}, \mathrm{N}$ contents in synthesized azo anils ligands and in $\mathrm{Cu}(\mathrm{II})$ complexes were found using CHNS technique (Costech international-4100). Metal contents in synthesized complexes were 
determined using Varian atomic absorption spectroscopy. The electronic spectra of azo anils and that of corresponding complexes was determined using Perkin-Elmer lambda-25 UV-Vis spectrophotometer and DMSO was used as solvent as well as reference. Jasco FT/IR (4100typeA) was used to determine FT/IR spectra (4000-400 $\mathrm{cm}^{-1}$ ) using $\mathrm{KBr}$ disk. Bruker $300 \mathrm{MHz}$ spectrometer was used to determine ${ }^{13} \mathrm{C}$ and ${ }^{1} \mathrm{H}$ NMR spectra.

\section{Synthesis of azo dye}

An azo dye, 2-hydroxy-5-[(4-nitrophenyl)diazenyl]benzaldehyde has been synthesized according to standard procedure [10]. In $4.14 \mathrm{~g}(30 \mathrm{mmol})$ of 4-nitroaniline, $40 \mathrm{~mL}$ of concentrated Hydrochloric acid and $20 \mathrm{~mL}$ of distilled water were added and heated up to $87^{\circ} \mathrm{C}$ until $p$-nitro aniline dissolved completely. Diazotization occurred below $5{ }^{\circ} \mathrm{C}$ when solution of $p$-nitro aniline was added to aqueous solution of sodium nitrite $(2.1 \mathrm{~g}, 30 \mathrm{mmol})$. Cooled diazonium solution was slowly poured to the salicyladehyde solution which was prepared by adding $3.2 \mathrm{~g}(30 \mathrm{mmol})$ of salicyladehyde in $65 \mathrm{~mL} \mathrm{H} \mathrm{H}_{2} \mathrm{O}$, which also contain $1.2 \mathrm{~g}$ of NaOH and $11.1 \mathrm{~g}$ of $\mathrm{Na}_{2} \mathrm{CO}_{3}$. The mixture was continuously stirred for $35 \mathrm{~min}$ within ice bath. The azo dye was obtained using gooch crucible. The obtained azo dye was washed with $20 \%$ sodium chloride solution. To salicyladehyde, diazonium occurred at (4-position from hydroxyl group). The end product was broadly washed with water and then with ethanol to remove any organic impurities. Formula, $\mathrm{C}_{13} \mathrm{H}_{9} \mathrm{~N}_{3} \mathrm{O}_{4}$, solid: yellow, yield: $78 \%$; m.p. $186-188{ }^{\circ} \mathrm{C}$; UV-Vis (DMSO) $\lambda_{\max } / \mathrm{nm}: 390$ and 542; The FT/IR $\left(\mathrm{KBr}, \mathrm{cm}^{-1}\right)$ : 3105 (-OH stretching of phenolic proton), 1660 (-CHO stretching of aldehydic group), $1475\left(\mathrm{~N}=\mathrm{N}\right.$ stretching of azo group), $1335\left(\mathrm{NO}_{2}\right.$ stretching of nitro group) and 1288 (C-O stretching of aromatic carbon and phenolic oxygen).

\section{Synthesis of azo anils ligands}

Azo anils ligands has been synthesised in accordance with published method [11]. Absolute ethanol $(60 \mathrm{~mL})$ was added to $4 \mathrm{mmol}$ of azo dye and stirred for $30 \mathrm{~min}$. Then ethanolic solutions of aniline, 2-methyl aniline and 1-naphthylamine each (4 mmol) were added to stirred solution of azo dye respectively and azo anils ligands (L1, L2 and L3) were obtained in consistent way. The whole reaction mixture was refluxed for $3 \mathrm{~h}$.

\section{4-[(4-Nitrophenyl)diazenyl]-2-[(phenylimino)methyl]phenol (L1)}

Reddish brown solid; yield: 75\%; m.p. 205-207 ${ }^{\circ} \mathrm{C}$; UV-Vis (DMSO) $\lambda \max / \mathrm{nm}$ : 292 and 337; FT/IR $\left(\mathrm{KBr}, \mathrm{cm}^{-1}\right)$ : 3270-3370 (-OH stretching of phenolic proton), 3640-3740 $\left(\mathrm{H}_{2} \mathrm{O}\right.$, stretching of coordinated water), 3053 ( $\mathrm{C}-\mathrm{H}$, stretching of aromatic hydrogen), $1660(-\mathrm{C}=\mathrm{N}$, stretching of azomethine group), $1608(-\mathrm{C}=\mathrm{C}-$, stretching of aromatic ring), $1435(-\mathrm{N}=\mathrm{N}-$, stretching of azo group), 1257 (C-O, stretching of aromatic carbon and phenolic oxygen); ${ }^{1} \mathrm{H}$ NMR (DMSO-d $\mathrm{d}_{6}$ )

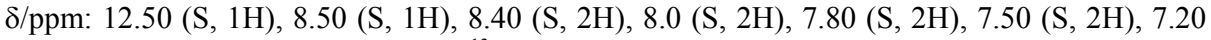

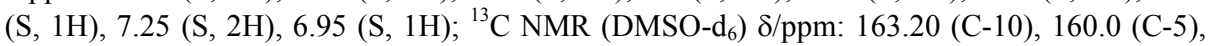
152.40 (C-14), 151.50 (C-6), 150.40 (C-15), 129.20 (C-22), 126.10 (C-13) ,125.50 (C-4), 124.50 (C-12), 123.40 (C-23), 118.50 (C-8), 113.2 (C-3). Elemental analysis: calcd. mass fractions of elements, $\mathrm{w} / \mathrm{w} \%$ for $\mathrm{C}_{19} \mathrm{H}_{14} \mathrm{~N}_{4} \mathrm{O}_{3} \cdot \mathrm{H}_{2} \mathrm{O}(\mathrm{MW}=364.35)$ are: $\mathrm{C} 62.63, \mathrm{H} 4.43, \mathrm{~N}$ 15.38, O 17.56; found: C 62.60, H 4.45, N 15.40, O 17.53.

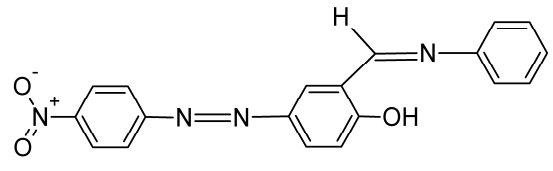

(L1)

Figure 1. Structure of 4-[(4-nitrophenyl)diazenyl]-2-[(phenylimino)methyl]phenol. 
2-\{[(2-Methylphenyl)imino]methyl\}-4-[(4-nitrophenyl)diazenyl]phenol (L2)

Bright brown solid, yield: $73 \%$, m.p. $240-245^{\circ} \mathrm{C}$; UV-Vis (DMSO) $\lambda_{\max } / \mathrm{nm}$ : 291 and 338; FTIR $\left(\mathrm{KBr}, \mathrm{cm}^{-1}\right)$ : $3275-3380\left(-\mathrm{OH}\right.$, stretching of phenolic proton), 3650-3750 $\left(\mathrm{H}_{2} \mathrm{O}\right.$, stretching of coordinated water), $3060 \mathrm{C}-\mathrm{H}$, stretching of aromatic hydrogen), $1655(-\mathrm{C}=\mathrm{N}$, stretching of azomethine group), $1615(-\mathrm{C}=\mathrm{C}-$, stretching of aromatic ring), $1430(-\mathrm{N}=\mathrm{N}-$, stretching of azo group), 1255 (C-O, stretching of aromatic carbon and phenolic oxygen); ${ }^{1} \mathrm{H}$ NMR (DMSO-d $\left.\mathrm{d}_{6}\right)$

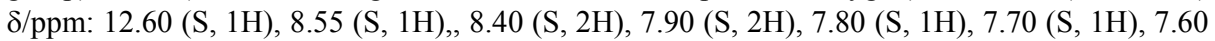
$(\mathrm{S}, 1 \mathrm{H}), 7.40(\mathrm{~S}, 1 \mathrm{H}), 7.20(\mathrm{~S}, 1 \mathrm{H}), 6.92(\mathrm{~S}, 2 \mathrm{H}), 2.10(\mathrm{~S}, 1 \mathrm{H}) .{ }^{13} \mathrm{C}$ NMR $\left(\mathrm{DMSO}_{6}\right)$ 8/ppm: 163.30 (C-11), 160.20 (C-6), 153.10 (C-15), 127.20 (C-23), 126.80 (C-14), 125.60 (C-18), 124.70 (C-5), 123.20 (C-13), 119.40 (C-8), 118.80 (C-24), 118.20 (C-1), 112.30 (C-4). Elemental analysis: calcd. mass fractions of elements, w/w\% for $\mathrm{C}_{20} \mathrm{H}_{16} \mathrm{~N}_{4} \mathrm{O}_{3} \cdot \mathrm{H}_{2} \mathrm{O}(\mathrm{MW}=$ 378.38) are: C 63.48, H 4.79, N 14.81, O 16.91; found: C 63.49, H 4.78, N 14.82, O 16.87.

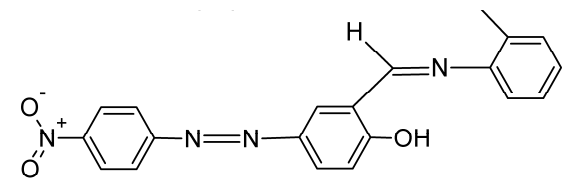

Figure 2. Structure of 2-\{[(2-methylphenyl)imino $]$ methyl $\}-4-[(4-$ nitrophenyl)diazenyl $]$ phenol.

2-[(Naphthalen-1-ylimino)methyl]-4-[(4-nitrophenyl)diazenyl]phenol (L3)

Yellowish green solid; yield: 71\%; m.p. $270-275{ }^{\circ} \mathrm{C}$; UV-Vis (DMSO) $\lambda_{\max } / \mathrm{nm}$ : 290 and 338; FTIR $\left(\mathrm{KBr}, \mathrm{cm}^{-1}\right)$ : 3272-3375 (-OH, stretching of phenolic proton), 3643-3740 $\left(\mathrm{H}_{2} \mathrm{O}\right.$, stretching of coordinated water), $3048 \mathrm{C}-\mathrm{H}$, stretching of aromatic hydrogen), $1655(-\mathrm{C}=\mathrm{N}$, stretching of azomethine group), $1616(-\mathrm{C}=\mathrm{C}-$, aromatic $), 1432(-\mathrm{N}=\mathrm{N}-$, stretching of azo group), 1360 (C-O, phenolic); ${ }^{1} \mathrm{H}$ NMR (DMSO-d $\left.{ }_{6}\right) \delta /$ ppm: $12.40(\mathrm{~S}, 1 \mathrm{H}), 8.60(\mathrm{~S}, 1 \mathrm{H}), 8.50(\mathrm{~S}, 3 \mathrm{H}), 8.10(\mathrm{~S}, 1 \mathrm{H})$, $7.90(\mathrm{~S}, 2 \mathrm{H}), 7.85(\mathrm{~S}, 2 \mathrm{H}), 7.70(\mathrm{~S}, 1 \mathrm{H}), 7.60(\mathrm{~S}, 2 \mathrm{H}), 7.55(\mathrm{~S}, 1 \mathrm{H}), 7.10(\mathrm{~S}, 1 \mathrm{H}) ;{ }^{13} \mathrm{C} \mathrm{NMR}$ $\left(\mathrm{DMSO}_{6}\right.$ ) $\delta / \mathrm{ppm}$ : 162.50 (C-10), 160.20 (C-5), 152.60 (C-14), 150.20 (C-6), 148.40 (C-15), 147.40 (C-25), 135.30 (C-26), 130.50 (C-27), 126.40 (C-22), 125.50 (C-13), 124.90 (C-17), 124.80 (C-24), 124.50 (C-4), 123.0 (C-12), 122.30 (C-16), 118.90 (C-8), 113.50 (C-23), 112.50 (C-3). Elemental analysis: calcd. mass fractions of elements, w/w $\%$ for $\mathrm{C}_{23} \mathrm{H}_{16} \mathrm{~N}_{4} \mathrm{O}_{3} \cdot \mathrm{H}_{2} \mathrm{O}(\mathrm{MW}=$ 414.41) are: C 66.66; H 4.38; N 13.52, O 15.44; found: C 66.65, H 4.39, N 13.51, O 15.46.

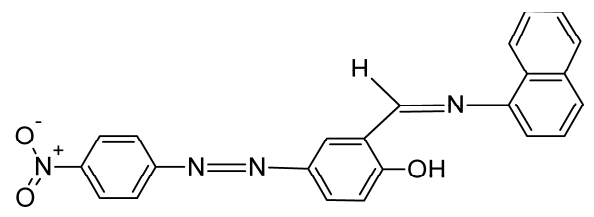

Figure 3. Structure of 2-[(naphthalen-1-ylimino)methyl]-4-[(4-nitrophenyl)diazenyl]phenol.

\section{Synthesis of copper(II) complexes}

The stirred ethanolic solution of $\mathrm{CuCl}_{2} \cdot 2 \mathrm{H}_{2} \mathrm{O}(1 \mathrm{mmol})$ was added to stirred solution of oxalic acid $(1 \mathrm{mmol})$ and azo anils $(1 \mathrm{mmol})$. A colour change was observed after addition of $\mathrm{CuCl}_{2} \cdot 2 \mathrm{H}_{2} \mathrm{O}$ solution. To ensure completion of reaction, the reaction mixture was refluxed for 4 
h. Gooch crucible was used to obtain precipitated product and washed again and again with ethanol.

\section{[4-[(4-Nitrophenyl)diazenyl]-2-[(phenylimino)methyl]phenolCu(II)(OX)]}

Brown solid; yield: $45 \%$; m.p. $>350{ }^{\circ} \mathrm{C}$; UV-Vis (DMSO) $\lambda_{\max } / \mathrm{nm}$ : 287 and 333; FTIR $(\mathrm{KBr}$, $\left.\mathrm{cm}^{-1}\right)$ : $1638(\mathrm{C}=\mathrm{N}$, stretching of azomethine group), 1425 to $(\mathrm{N}=\mathrm{N}$, stretching of azo group), 1333 (C-O, stretching of aromatic carbon and phenolic oxygen). The band such as 458, 588 correspond to $\mathrm{Cu}-\mathrm{N}$ and $\mathrm{Cu}-\mathrm{O}$ bonds, respectively. Elemental analysis: calcd. mass fractions of elements, $\mathrm{w} / \mathrm{w} \%$ for $\mathrm{C}_{21} \mathrm{H}_{13} \mathrm{CuN}_{4} \mathrm{O}_{7}(\mathrm{MW}=496.89)$ are: $\mathrm{C} 50.76, \mathrm{H} 2.64, \mathrm{~N} 11.28, \mathrm{Cu}(\mathrm{II})$, 12.79; found: C 50.74, H 2.62, N 11.30, Cu(II), 12.81 .

\section{[2-\{[(2-Methylphenyl)imino]methyl\}-4-[(4-nitrophenyl)diazenyl]phenolCu(II)(OX)]}

Yellowish brown solid; yield: 50\%; m.p. $>350{ }^{\circ} \mathrm{C}$; UV-Vis (DMSO) $\lambda_{\max } / \mathrm{nm}: 289$ and 331 ; FTIR $\left(\mathrm{KBr}, \mathrm{cm}^{-1}\right): 1625(\mathrm{C}=\mathrm{N}$, stretching of azomethine group), $1430(\mathrm{~N}=\mathrm{N}$, stretching of azo group), 1333 (C-O, stretching of aromatic carbon and phenolic oxygen). The band such as 460, 590 correspond to $\mathrm{Cu}-\mathrm{N}$ and $\mathrm{Cu}-\mathrm{O}$ bonds, respectively. Elemental analysis: calcd. mass fractions of elements, $\mathrm{w} / \mathrm{w} \%$ for $\mathrm{C}_{22} \mathrm{H}_{15} \mathrm{~N}_{4} \mathrm{O}_{7} \mathrm{Cu}(\mathrm{MW}=510.92)$ are: $\mathrm{C} 51.72, \mathrm{H} 2.96, \mathrm{~N} 10.97$, $\mathrm{Cu}(\mathrm{II}), 12.44$; found: $\mathrm{C} 51.70, \mathrm{H} 2.93, \mathrm{~N} 10.98, \mathrm{Cu}(\mathrm{II}), 12.45$.

\section{[2-[(Naphthalen-1-ylimino)methyl]-4-[(4-nitrophenyl)diazenyl]phenolCu(II)(OX)]}

Light brown solid; yield: $47 \%$; m.p. $>350{ }^{\circ} \mathrm{C}$; UV-Vis (DMSO) $\lambda_{\max } / \mathrm{nm}$ : 287 and 330; FTIR $\left(\mathrm{KBr}, \mathrm{cm}^{-1}\right): 1625(\mathrm{C}=\mathrm{N}$, stretching of azomethine group), $1430(\mathrm{~N}=\mathrm{N}$, stretching of azo group), 1333 (C-O, stretching of aromatic carbon and phenolic oxygen). The band such as 462, 592 correspond to $\mathrm{Cu}-\mathrm{N}$ and $\mathrm{Cu}-\mathrm{O}$ bonds, respectively. Elemental analysis: calcd. mass fractions of elements, $\mathrm{w} / \mathrm{w} \%$ for $\mathrm{C}_{25} \mathrm{H}_{15} \mathrm{~N}_{4} \mathrm{O}_{7} \mathrm{Cu}(\mathrm{Mr}=546.96)$ are: $\mathrm{C} 54.90, \mathrm{H} 2.76, \mathrm{~N} 10.24, \mathrm{Cu}, 11.62$; found: $\mathrm{C} 54.93, \mathrm{H} 2.73, \mathrm{~N} 10.23, \mathrm{Cu}, 11.65$.

\section{Antibacterial activities}

The diffusion disc method was used for determination of antibacterial activities of azo anils and their mixed ligands $\mathrm{Cu}$ (II) complexes [12-17]. The glass wares were sterilized for $1 \mathrm{~h}$ at $170{ }^{\circ} \mathrm{C}$. The agar medium was prepared by the addition of nutrient agar $(2.8 \mathrm{~g})$ and agar technical $(1 \mathrm{~g})$ in $100 \mathrm{~mL}$ water (distilled). The homogeneous mixture was boiled for $1 / 2 \mathrm{~h}$, followed by cooling. Dil. $\mathrm{HCl}$ and dil. $\mathrm{NaOH}$ were used for the adjustment of $\mathrm{pH}$ at 7.4. The agar medium was autoclaved for $15 \mathrm{~min}$ at $121{ }^{\circ} \mathrm{C}$ [18]. Agar medium $(30-35 \mathrm{~mL})$ was spread on Petri dishes using glass spreader and incubated at $37{ }^{\circ} \mathrm{C}$ for a period of $24 \mathrm{~h}$. A measured quantity of test compound was added in DMSO to attain a concentration of $1000 \mathrm{mg} / \mathrm{L}$. In two Petri dishes $(9$ $\mathrm{cm}$, diameter), the agar medium was spread using sterilized spreader and after solidifying the medium, $0.2 \mathrm{~mL}$ of Gram positive (Bacillus subtilis and Staphylococcus aureus) and Gram negative (Enterobacter aerogenes and Escherichia coli) bacteria were spread respectively over it and incubated. The discs $(6.00 \mathrm{~mm}$, diameter) of Whatmann filter paper were soaked in the solution of test compound and located on Petri dishes which were incubated for 48 hours at 37 ${ }^{\circ} \mathrm{C}$. The area of inhibition was evaluated in millimetres.

A given amount of DMSO $(0.2 \mathrm{~mL})$ under same conditions was also taken as a standard for Gram positive (Bacillus subtilis and Staphylococcus aureus) and Gram negative (Enterobacter aerogenes and Escherichia coli) bacteria. The thickness of inhibition zone originating from DMSO was subtracted from the inhibition zone originating from test compounds and means of three replicate reading determined antibacterial activities. 
Table 2. Measurement of antibacterial activities of test compounds against gram positive and gram negative bacteria.

\begin{tabular}{|c|c|c|c|c|c|}
\hline \multirow{4}{*}{$\begin{array}{l}\text { Name of } \\
\text { compound }\end{array}$} & \multirow{4}{*}{$\begin{array}{l}\text { Volume of } \\
\text { compound } \\
(\mu \mathrm{L})\end{array}$} & \multicolumn{4}{|c|}{ Diameter of inhibition zone measured (mm) } \\
\hline & & \multicolumn{4}{|c|}{ Bacterial species } \\
\hline & & \multicolumn{2}{|c|}{ Gram positive } & \multicolumn{2}{|c|}{ Gram negative } \\
\hline & & $\begin{array}{l}\text { Bacillus } \\
\text { Subtilis }\end{array}$ & $\begin{array}{c}\text { Staphylococcus } \\
\text { aureus }\end{array}$ & $\begin{array}{l}\text { Enterobacter } \\
\text { aerogenes }\end{array}$ & $\begin{array}{c}\text { Escherichia } \\
\text { coli }\end{array}$ \\
\hline $\mathrm{CuCl}_{2} \cdot 2 \mathrm{H}_{2} \mathrm{O}$ & 20 & $4 \pm 1.0$ & $4 \pm 1.0$ & $4 \pm 1.0$ & $3 \pm 1.0$ \\
\hline Oxalic acid & 20 & $2 \pm 1.0$ & $3 \pm 1.0$ & $4 \pm 1.0$ & $4 \pm 1.0$ \\
\hline $\mathrm{C}_{19} \mathrm{H}_{14} \mathrm{~N}_{4} \mathrm{O}_{3} \cdot \mathrm{H}_{2} \mathrm{O}(\mathrm{L} 1)$ & 20 & $5 \pm 1.0$ & $8 \pm 1.0$ & $4 \pm 1.0$ & $8 \pm 1.0$ \\
\hline $\mathrm{C}_{20} \mathrm{H}_{16} \mathrm{~N}_{4} \mathrm{O}_{3} \cdot \mathrm{H}_{2} \mathrm{O}(\mathrm{L} 2)$ & 20 & $8 \pm 1.0$ & $8 \pm 1.0$ & $5 \pm 1.0$ & $8 \pm 1.0$ \\
\hline $\mathrm{C}_{23} \mathrm{H}_{16} \mathrm{~N}_{4} \mathrm{O} 3 . \mathrm{H}_{2} \mathrm{O}(\mathrm{L} 3)$ & 20 & $9 \pm 1.0$ & $8 \pm 1.0$ & $8 \pm 1.0$ & $7 \pm 1.0$ \\
\hline$\{(\mathrm{L} 1) \mathrm{Cu}(\mathrm{II})(\mathrm{OX})\}$ & 20 & $14 \pm 1.0$ & $14 \pm 1.0$ & $12 \pm 1.0$ & $10 \pm 1.0$ \\
\hline$\{(\mathrm{L} 2) \mathrm{Cu}(\mathrm{II})(\mathrm{OX})\}$ & 20 & $10 \pm 1.0$ & $13 \pm 1.0$ & $14 \pm 1.0$ & $14 \pm 1.0$ \\
\hline$\{(\mathrm{L} 3) \mathrm{Cu}(\mathrm{II})(\mathrm{OX})\}$ & 20 & $14 \pm 1.0$ & $12 \pm 1.0$ & $13 \pm 1.0$ & $14 \pm 1.0$ \\
\hline${ }^{* 2}$ Streptomycin & 20 & $5 \pm 1.0$ & $7 \pm 1.0$ & $8 \pm 1.0$ & $10 \pm 1.0$ \\
\hline
\end{tabular}

These values are expressed as a mean of three replicate reading $( \pm \mathrm{SD})$.

\section{FTIR spectra}

\section{RESULTS AND DISCUSSION}

FTIR spectra of synthesized azo anils and mixed ligands complexes (azo anils and oxalate ion) were performed over $\mathrm{KBr}\left(4000-400, \mathrm{~cm}^{-1}\right)$. FT/IR bands in the range 1645-1655, correspond to coordinated oxalate group, verified from similar complexes [19]. FT/IR spectra comparison revealed that the absorption bands in the region 3270-3380 due to $-\mathrm{OH}$ (phenolic group) was not appeared in mixed ligands complexes, an indication for the loss of phenolic proton upon formation of complexes. The new absorption band in $\mathrm{Cu}$ (II) spectra at 588-590 correspond to $\mathrm{Cu}-\mathrm{O}$ bond. In azo anils ligands the absorption bands at 1655-1660 was assigned to azomethine $(-\mathrm{C}=\mathrm{N})$ group, which upon complexation shifted toward lower stretching frequency 1630-1625. Lessened double bond character of $(-\mathrm{C}=\mathrm{N})$ azomethine was caused due to coordination between metal and nitrogen of azomethine group. The absorption band at 458-462 was consigned to $\mathrm{Cu}-$ $\mathrm{N}$ bond which was confirmed from similar complexes [20-22]. The band at 758 correspond to (-OCO) group as reported earlier [19].

\section{Electronic spectra of azo anils ligands and $\mathrm{Cu}(\mathrm{II})$ complexes}

The electronic spectra of all three azo anils ligands (L1, L2 and L3) displayed two absorption bands at $290 \mathrm{~nm}$ and $335 \mathrm{~nm}$ which were assigned to $\pi \rightarrow \pi^{*}$ (phenyl rings) and $\mathrm{n} \rightarrow \pi^{*}(\mathrm{H}-\mathrm{C}=\mathrm{N}$ and azomethine group) transitions respectively as reported earlier [23]. Electronic spectra regarding mixed ligands (azo anils and oxalate) complexes of copper(II) exhibited two absorption bands at $288 \mathrm{~nm}$ and $330 \mathrm{~nm}$ which were corresponded to $\mathrm{d}-\mathrm{d}$ and ${ }^{2} \mathrm{~B}_{1 \mathrm{~g}} \rightarrow{ }^{2} \mathrm{E}_{\mathrm{g}}$, transitions and square planner geometry was suggested for $\mathrm{Cu}$ (II) complexes as reported earlier [24].

\section{${ }^{13} \mathrm{C}-{ }^{1} \mathrm{H}-\mathrm{NMR}$ spectra of azo anils}

${ }^{13} \mathrm{C}$ and ${ }^{1} \mathrm{H}-\mathrm{NMR}$ spectra of azo anils were recorded in (DMSO- $\left.\mathrm{d}_{6}\right)$ solvent. ${ }^{1} \mathrm{H}-\mathrm{NMR}$ exhibited peaks at 12.60-12.40 ppm and 8.40-8.10 ppm which could be assigned to phenolic and azomethine protons respectively. In ${ }^{13} \mathrm{C}$-NMR, the peaks appeared in the range of 113.60-160.40 ppm which could be assigned to aromatic carbon and signal at $163.30 \mathrm{ppm}$ to azomethine group. 


\section{Antibacterial activities evaluation}

The strain of Gram positive (Bacillus subtilis and Staphylococcus aureus) and Gram negative (Enterobacter aerogenes and Escherichia coli) bacteria were used for the measurement of antibacterial activities of copper chloride dihydrate, oxalic acid, azo anils and copper(II) complexes. Streptomycin an antibacterial drug, under same conditions was used to compare antibacterial activities of azo anils and respective $\mathrm{Cu}$ (II) complexes. The observations given in Table 3 showed that $\mathrm{Cu}(\mathrm{II})$ complexes exhibited sky-scraping antibacterial activities as compared $\mathrm{CuCl}_{2} \cdot 2 \mathrm{H}_{2} \mathrm{O}$, azo anils and oxalate ion. The Tweedy's chelation theory and Searl's idea described, why antibacterial activities of metal complexes enhanced [25].

Table 3. Results of antibacterial activities test compounds against gram positive and gram negative bacteria ${ }^{*}$.

\begin{tabular}{|l|c|c|c|c|}
\hline \multirow{2}{*}{ Compounds } & \multicolumn{2}{|c|}{ Gram positive } & \multicolumn{2}{c|}{ Gram negative } \\
\cline { 2 - 5 } & $\begin{array}{c}\text { B. } \\
\text { subtilis }\end{array}$ & S. aureus & E. aerogenes & \multirow{2}{*}{ E.coli } \\
\hline $\mathrm{CuCl}_{2} \cdot 2 \mathrm{H}_{2} \mathrm{O}$ & +++ & +++ & +++ & +++ \\
\hline Oxalic acid & +++ & +++ & +++ & +++ \\
\hline $\mathrm{C}_{19} \mathrm{H}_{14} \mathrm{~N}_{4} \mathrm{O}_{3} \cdot \mathrm{H}_{2} \mathrm{O}(\mathbf{L 1})$ (Ligand \# L1) & +++ & ++++ & +++ & ++++ \\
\hline $\mathrm{C}_{20} \mathrm{H}_{16} \mathrm{~N}_{4} \mathrm{O}_{3} \cdot \mathrm{H}_{2} \mathrm{O}(\mathbf{L 2})$ (Ligand \# L2) & +++ & ++++ & +++ & ++++ \\
\hline $\mathrm{C}_{23} \mathrm{H}_{16} \mathrm{~N}_{4} \mathrm{O}_{3} \cdot \mathrm{H}_{2} \mathrm{O}(\mathbf{L} 3)($ Complex-1) & ++++ & ++++ & ++++ & +++ \\
\hline$\{(\mathrm{L} 1) \mathrm{Cu}(\mathrm{II})(\mathrm{OX})\}($ Complex-2) & +++++ & +++++ & +++++ & ++++ \\
\hline$\{(\mathrm{L} 2) \mathrm{Cu}(\mathrm{II})(\mathrm{OX})\}$ & +++++ & +++++ & +++++ & ++++ \\
\hline$\{(\mathrm{L} 3) \mathrm{Cu}(\mathrm{II})(\mathrm{OX})\}$ & +++++ & +++++ & +++++ & +++++ \\
\hline${ }^{* 2} \mathrm{Streptomycin}$ & ++++ & ++++ & ++++ & +++ \\
\hline
\end{tabular}

${ }^{*}$ Antibacterial activity was measured using disc diffusion method: disc diameter $=6 \mathrm{~mm}$; inhibition zone $=1-5$ $\mathrm{mm}$ beyond control limit $=+++($ less active $)$; inhibition zone $=6-10 \mathrm{~mm}$ beyond control limit $=++++($ moderately active); inhibition zone $=11-15 \mathrm{~mm}$ beyond control limit $=+++++($ highly active $)$; inhibition zone $=0$ (resistant to bacteria). ${ }^{* 2}$ Streptomycin: standard antibacterial drug.

The results showed that antibacterial activities of azo anils enhance, when these free azo anils ligands were coordinated to transition metal atom. The antibacterial activities of mixed ligands $\mathrm{Cu}(\mathrm{II})$ complexes were higher than corresponding ligands due to their structural symmetry or structural features, i.e. electron withdrawing group (nitro and azomethine) connected to benzene ring. It has been believed that azo anils (or Schiff base) having nitrogen and oxygen system retard enzymatic activities of bacteria later than coordination to transition metal atom.

\section{CONCLUSION}

Here we are reporting, three mixed ligands $\mathrm{Cu}(\mathrm{II})$ complexes, synthesized from azo anils namely, 4-[(4-nitrophenyl)diazenyl]-2-[(phenylimino)methyl]phenol (L1), 2-\{[(2-methylphenyl)imino]methyl\}-4-[(4-nitrophenyl)diazenyl]phenol (L2) and 2-[(naphthalen-1ylimino)methyl]-4-[(4-nitrophenyl)diazenyl]phenol (L3) and oxalate ligands, respectively. Elemental analysis, AAS, FT/IR and UV-Vis spectroscopy determined square planner geometry for these copper(II) complexes. Copper chloride dihydrate, azo anils, oxalic acid and $\mathrm{Cu}(\mathrm{II})$ complexes were screened out for their antibacterial activities against Gram positive (Bacillus subtilis and Staphylococcus aureus) and Gram negative (Enterobacter aerogenes and Escherichia coli) bacteria. The results showed that $\mathrm{Cu}(\mathrm{II})$ complexes exhibit higher antibacterial 
activities as compared to free ligands and metal salt due to structural geometry and electron withdrawing group (nitro and azomethine) connected to benzene ring. The order of antibacterial activities of $\mathrm{Cu}(\mathrm{II})$ complexes was $\{\mathrm{L} 1 \mathrm{Cu}(\mathrm{II})(\mathrm{OX})\}>\{\mathrm{L} 2 \mathrm{Cu}(\mathrm{II})(\mathrm{OX})\}>\{\mathrm{L} 3 \mathrm{Cu}(\mathrm{II})(\mathrm{OX})\}$.

In future an effort could be made to prepare $\mathrm{Ni}(\mathrm{II}), \mathrm{Zn}(\mathrm{II}), \mathrm{Cd}(\mathrm{II})$ mixed ligands complexes using these azo anils ligands and oxalate ion because these transition metals and copper(II) have similar chemical characteristics.

\section{ACKNOWLEDGMENT}

The author is thankful to Department of Microbiology, PCSIR, Lahore, Pakistan for their cooperation in the biological study of synthesized ligands and complexes.

\section{REFERENCES}

1. Sakyan, I.; Logoglu, E.; Arsalan, S.; Sari, N.; Akiyan, N. Biometals 2004, 17, 115.

2. Hemant, K.; Ram, P.C. Scholars Res. Lib. 2010, 2, 407

3. Lau, K.Y.; Mayr, A.; Cheung, K.K. Inorg. Chim. Acta 1999, 285, 223.

4. Dholakiya, P.P.; Patel, M.N. Inorg Met. Org. Chem. 2004, 4, 553.

5. Chohan, Z.H.; Praveen, M.; Ghaffar, M. Metal Based Drugs 1997, 4, 267.

6. Nirmal, R.; Prakesh, C.R.; Menakshi, K.; Shanmugapandiyan, P. J. Young Pharm. 2010, 2, 162.

7. Pontiki, E.; Litina, D.H.; Chaviara, A.T. J. Enzyme Med. Chem. 2008, 23, 1011.

8. Wang, P.H.; Keck, J.G.; Lien, E.J.; Lai, M.M.C. J. Med. Chem. 1990, 33, 608

9. Arjmand, F.; Mohani, B.; Ahmad, S. Eur. J. Med. Chem. 2005, 40, 1103.

10. Botros, R. US Patent 1977, 4051119.

11. Rezvani, Z.; Ghanea, M.A.; Nejati, K. Polyhedron 2009, 28, 2913.

12. Ferrari, M.B.; Capacchi, S.; Pelosi, G.; Reffo, G.; Tarasconi, P.; Albertini, R.; Pinelli, S.; Lunghi, P. Inorg. Chim. Acta 1999, 286, 134.

13. Chohan, Z.H.; Sheazi, S.K.A. Inorg. Met. Org. Chem. 1999, 29, 105.

14. Jayabalakrishnan, C.; Natarajan, K. Inorg. Met. Org. Chem. 2001, 31, 983.

15. Jeeworth, T.; Wah, H.L.K.; Bhowon, G.D.; Babooram, K. Inorg. Met. Org. Chem. 2000, 30, 1023.

16. Dharmaraj, N.; Viswanathamurthi, P.; Natarajan, K. Trans. Met. Chem. 2001, 26, 105.

17. Colins, C.H.; Lyne, P.M. in Microbial Methods, University Park Press: Baltimore; 1970; p 422.

18. Black, J.G.; Hall, P. Microbiology, Principles and Explorations, Springer: New York; 1993; p 334.

19. Bappaditya, B.; Nijhuma, M; Samiran, M.; Volker, G.; Joan, R.; El Fallah, M.S. Polyhedron 2001, 20, 2113.

20. Khandar, A.A.; Rezvani, Z. Polyhedron 1999, 18, 129.

21. Rezvani, Z.; Ahar, L.; Nejati, K.; Seyeda, Hmadian, S.M. Acta Chim. Slov. 2004, 51, 675.

22. Erdem, E.; Sari, E.Y.; Kilinçarslan, R.; Kabay, N. Trans. Metal Chem. 2009, 34, 167.

23. Abdlseed, F.A.; El-ajaily, M. Int. J. Pharm. Tech. Res. 2009, 1, 1097.

24. Sunalsuki, Y.; Motada, Y.N. Coord. Chem. Rev. 2002, 226, 199.

25. Dharamaraj, N. Viswanathamurthi, P.; Natarajan, K. Trans. Metal Chem. 2001, 26, 105. 